\title{
FEASIBILITY OF UTILIZATION OF CHARCOAL AND ASHES FROM BIOMASS-ENERGY PROCESSES IN CONSTRUCTION MATERIALS
}

\author{
NANCY QUARANTA ${ }^{1 *}$, MARTA CALIGARIS ${ }^{1}$, GISELA PELOZO $^{1}$ \& ADRIÁN CRISTÓBAL ${ }^{2}$ \\ ${ }^{1}$ Universidad Tecnológica Nacional, Facultad Regional San Nicolás, Argentina \\ ${ }^{2}$ INTEMA-CONICET, Universidad Nacional de Mar del Plata, Argentina
}

\begin{abstract}
Biomass-energy processes are those used to obtain energy by the burning or biochemical converting of any organic matter to be used for fuel. In recent years, some materials used as a source for biomass energy have been obtained from the discards of agricultural activities. These include wood, sawdust, corn, sugarcane and rice husks, among others. The processes for converting biomass into energy are numerous. The most commonly used are combustion, co-firing process and pyrolysis. The residual endproducts obtained from these processes are highly dependent on the process conditions, especially temperature, pressure and atmosphere. Char and ashes are the most commonly obtained materials. The objective of this work is to analyse the feasibility of reusing these discards of biomass-energy processes, as additions in clay mixtures for the production of ceramic materials for civil construction. For this purpose, charcoal and ashes obtained from various biomasses have been characterized by SEM, EDS, DTA-TGA, XRD, etc. These results, and the determination of the theoretical sintering temperatures by the use of ternary diagrams, lead to the establishment of the feasibility of using these discards in current ceramic industry processes. Charcoal and ashes from sunflower husks, brewery waste and pine sawdust are the materials studied.
\end{abstract}

Keywords: biomass-energy, construction materials, charcoals and ashes.

\section{INTRODUCTION}

Biomass wastes are organic materials, originating from a natural or induced process, that can be used as a source of energy, that is to say, organic waste materials that can be used as fuel. Consequently, biomass is likely to be a successful resource because of its wide availability. In the case of discards obtained from biomass processes, two types of waste can be considered: firstly, those that remain as residual materials of the productive process itself, such as pits or shells; and secondly, the ashes, which constitute the final residue obtained from actually using these process residues as fuels to produce energy. The characteristics of the ashes derived from the combustion of biomass have been reported in different studies [1], [2].

The use of biomass ash in soil has enormous potential. Several authors have analysed the effects on soils of biomass ashes from various materials [3]-[5].

Diverse biomasses for the production of activated carbon have been studied: beer lees waste [6], plane tree seeds [7], biochar [8], peanut shells [9], olive stones and walnut shells [10]. There are precedents for the use of biomass ashes in the construction industry, with different biomass ashes being studied for use in cement-based building materials [11]-[15]. The incorporation of the biomass ashes of sugarcane bagasse and rice husk [16], wood ashes [17] and olive pomace [18], in the manufacture of clay bricks has also been investigated.

The use of sunflower seed husks as a supplementary fuel in the iron ore sintering process [19], for the removal of dye from the textile industry's wastewater effluent [20], or for obtaining bio-oils [21], has also been studied.

* CIC Researcher 
Furthermore, the utilization of residual-biomass generated in distilleries and breweries for the production of added-value products has been reviewed [22].

This paper analyses the feasibility of reusing charcoal and ashes from sunflower husks, brewery waste and sawdust, as additions in clay mixtures for the production of ceramic materials for civil construction.

\section{MATERIALS AND METHODS}

Sunflower husk ash (SHA), brewery waste char (BWC) and sawdust char (SC) were studied. The ashes of sunflower husks come from an oil manufacturer, which burns the husks in a boiler in the same company to take advantage of the energy that is produced. The companies obtained the chars by burning the residual biomass in wood ovens in order to take advantage of the caloric energy and to reduce the volume of waste that must be disposed of.

Those waste materials were characterized by optical microscopy $(\mathrm{OM})$, scanning electron microscopy (SEM) with X-ray electron dispersive analysis (EDS), X-ray diffraction (XRD), differential thermal analysis and thermogravimetric analysis (DTA-TGA).

SEM analyses were performed with FEI Inspect S50. The X-ray diffraction patterns of the residues were obtained with PANalytical X'Pert PRO equipment, with $\mathrm{CuK} \alpha$ radiation $(\lambda=$ $1.5406 \mathrm{~nm}$ ). The operating conditions were $40 \mathrm{kV}$ and $40 \mathrm{~mA}$. The TGA-DTA essays were conducted on a Shimadzu DTA-50 analyser TGA-50 with YC-50 WSI.

\section{RESULTS AND DISCUSSION}

The microstructure of sunflower husk ash is shown in Fig. 1, where a typical structure of agglomerates is observed. From the morphologic study of this material, the irregularity and heterogeneity of the particles are observed, probably due to the presence of a variety of phases.

In Fig. 2, the SEM images of pine sawdust char (a) and brewery waste char (b) are presented. As can be seen, both chars present a porous surface. In the case of sawdust char, the observed pores are those present in the original structure of the biomass, while the surface pores observed in the brewery waste char are produced during the biomass-burning process.

The morphology and pore size distribution in biochar depends on the composition of the feedstock materials and the temperature adopted during char formation [23].

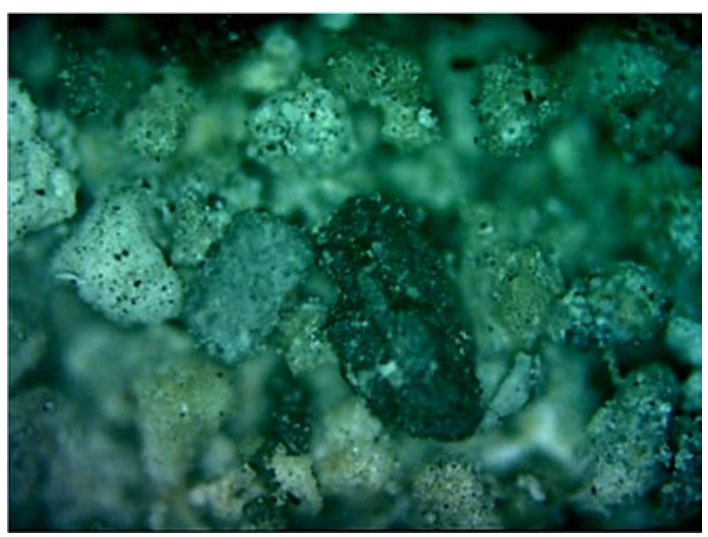

Figure 1: Optical microscopy image of sunflower husk ash. Magnification: 50X. 

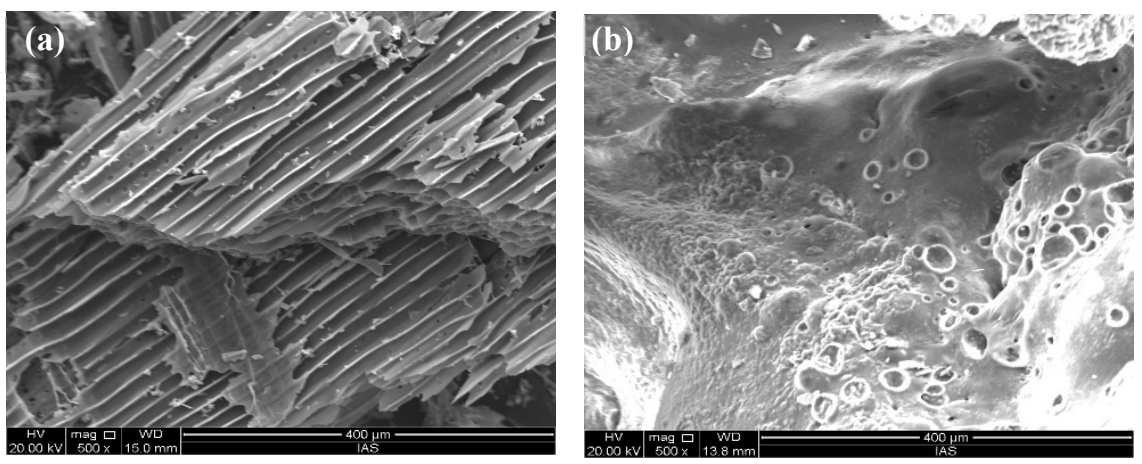

Figure 2: Scanning electron microscopy images of (a) Sawdust char; (b) Brewery waste char.

Table 1: EDS analysis of SHA (1), BWC (2) and SC (3).

\begin{tabular}{|c|c|c|c|c|c|c|c|c|c|c|c|c|}
\cline { 2 - 13 } \multicolumn{1}{c|}{} & $\mathrm{C}$ & $\mathrm{O}$ & $\mathrm{Na}$ & $\mathrm{Mg}$ & $\mathrm{Al}$ & $\mathrm{Si}$ & $\mathrm{P}$ & $\mathrm{Cl}$ & $\mathrm{K}$ & $\mathrm{Ca}$ & $\mathrm{Mn}$ & $\mathrm{Fe}$ \\
\hline 1 & 21.4 & 40.5 & -- & 15.6 & 1.1 & 4.0 & 4.8 & 0.1 & 4.6 & 7.9 & -- & -- \\
\hline 2 & 67.8 & 16.4 & 1.2 & 1.6 & -- & 4.1 & 4.1 & -- & 1.1 & 2.1 & -- & 1.6 \\
\hline 3 & 72.3 & 6.8 & -- & 0.3 & -- & 0.8 & 0.8 & -- & 2.1 & 4.2 & 2.2 & 10.5 \\
\hline
\end{tabular}

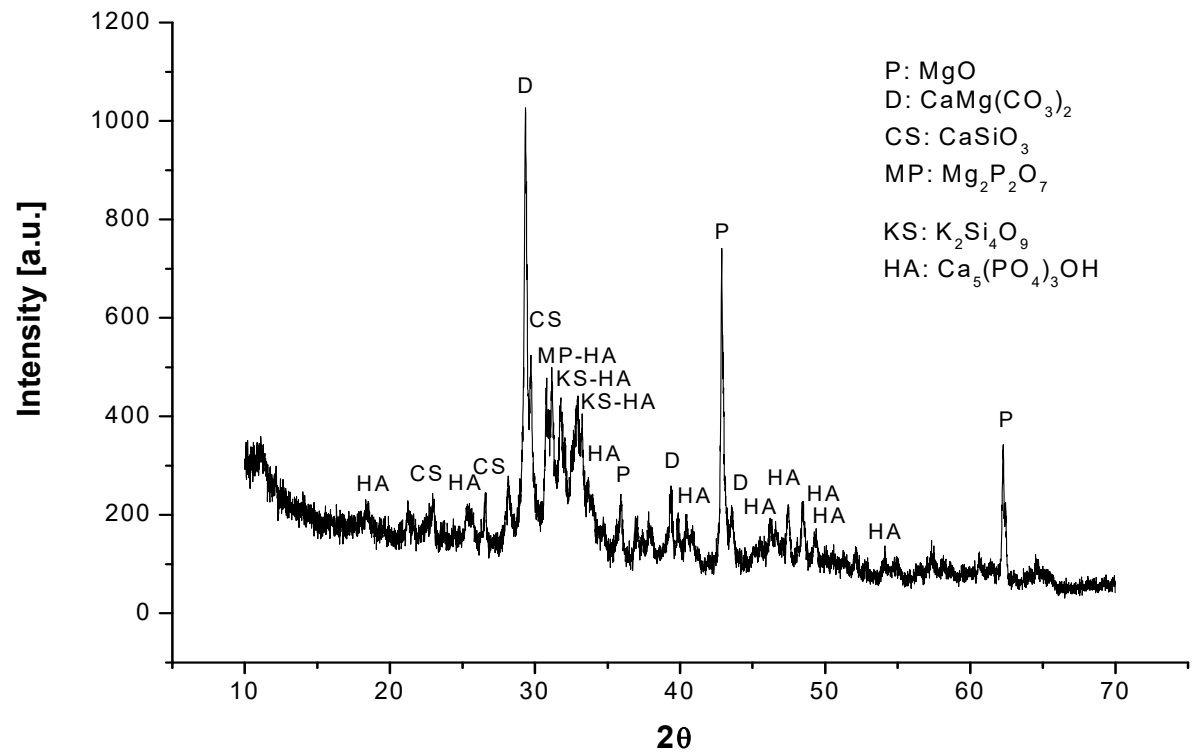

Figure 3: XRD pattern of SHA. 
Table 1 shows the semi-quantitative chemical analysis by EDS of the ash and chars studied, expressed as a percentage of the elements. As can be seen, all the samples present large quantities of carbon.

The XRD pattern of sunflower husk ash is presented in Fig. 3. It is observed that the residue is formed of a complex mixture of compounds, including dolomite $\left(\mathrm{CaMgCO}_{3}\right)$, periclase $(\mathrm{MgO})$, calcium silicate $\left(\mathrm{CaSiO}_{3}\right)$, magnesium pyrophosphate $\left(\mathrm{Mg}_{2} \mathrm{P}_{2} \mathrm{O}_{7}\right)$, potassium tetrasilicate $\left(\mathrm{K}_{2} \mathrm{Si}_{4} \mathrm{O}_{9}\right)$ and hydroxyapatite $\left(\mathrm{Ca}_{5}\left(\mathrm{PO}_{4}\right)_{3} \mathrm{OH}\right)$. Other authors [24] have also reported XRD patterns of sunflower husk ashes with a great variety of phosphates, carbonates and complex silicates.

The distinct sharp crystalline cellulosic peak $\left(2 \theta=24^{\circ}\right)$ that comes from the crystal structure of cellulose was observed in the XRD spectra of brewery waste char. Regarding the pine sawdust char, in addition to the crystalline cellulosic peak, other peaks were found, attributed to the presence of $\mathrm{CaCO}_{3}$ and $\mathrm{Fe}_{3} \mathrm{O}_{4}$. This is shown in Fig. 4.

Investigation of the thermal behaviour of the materials was carried out by DTA-TGA. Fig. 5 illustrates the SHA curves. An endothermic peak with loss of weight is observed at $125^{\circ} \mathrm{C}$, followed by an exothermic peak at approximately $300^{\circ} \mathrm{C}$. There, another exothermic peak is detected between $370^{\circ} \mathrm{C}$ and $470^{\circ} \mathrm{C}$. From $470^{\circ} \mathrm{C}$ to $800^{\circ} \mathrm{C}$, the sample continues losing weight, showing several very small peaks in the DTA curve. Some authors have attributed similar behaviours of these ashes to the reactions of water loss, combustion of the not burnt elements, and carbonate decomposition [25].

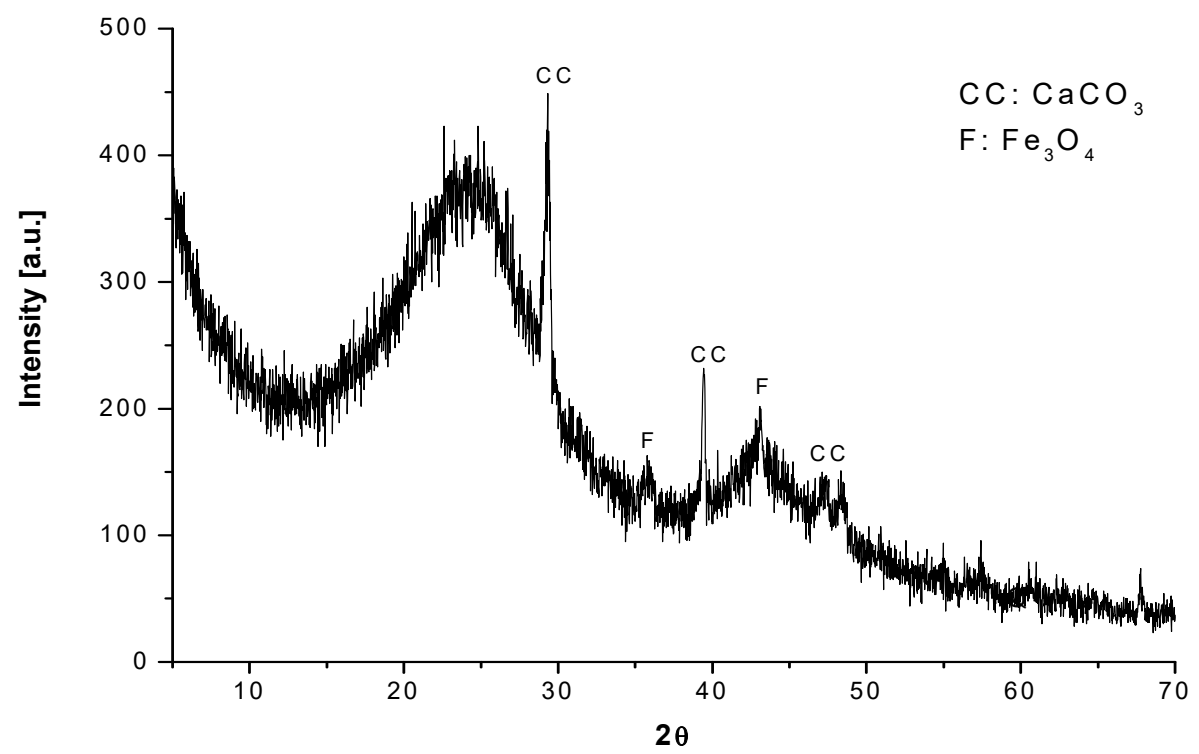

Figure 4: XRD pattern of SC. 


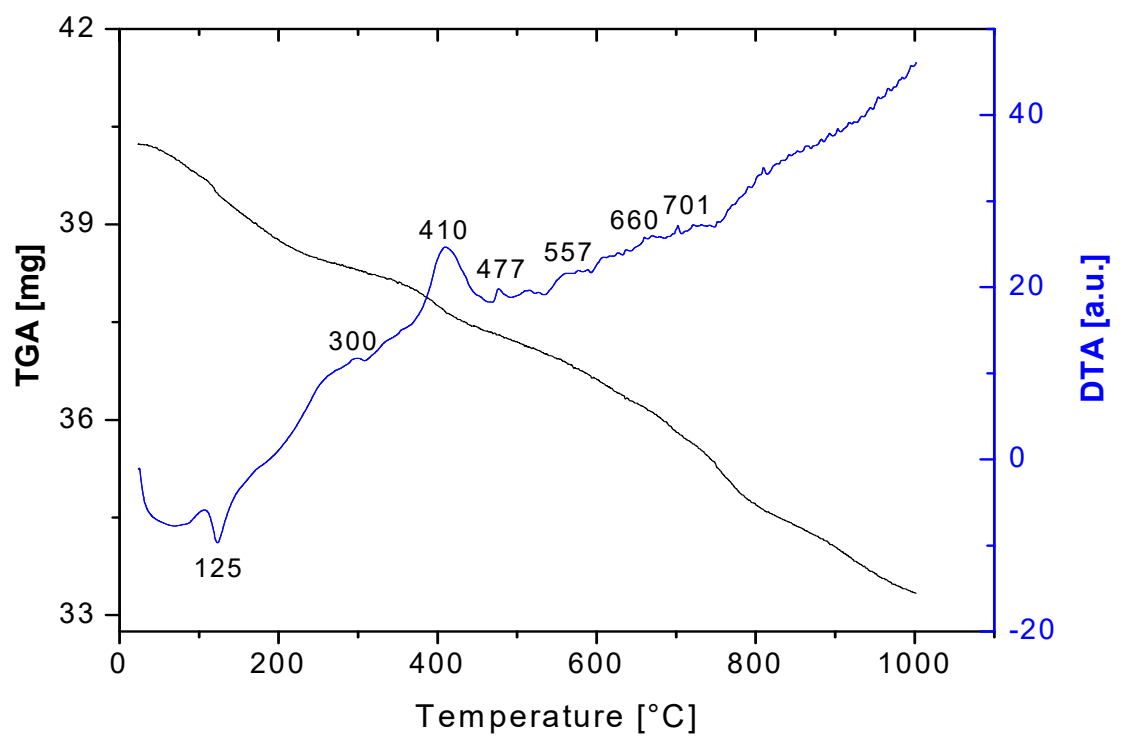

Figure 5: DTA-TGA of SHA.

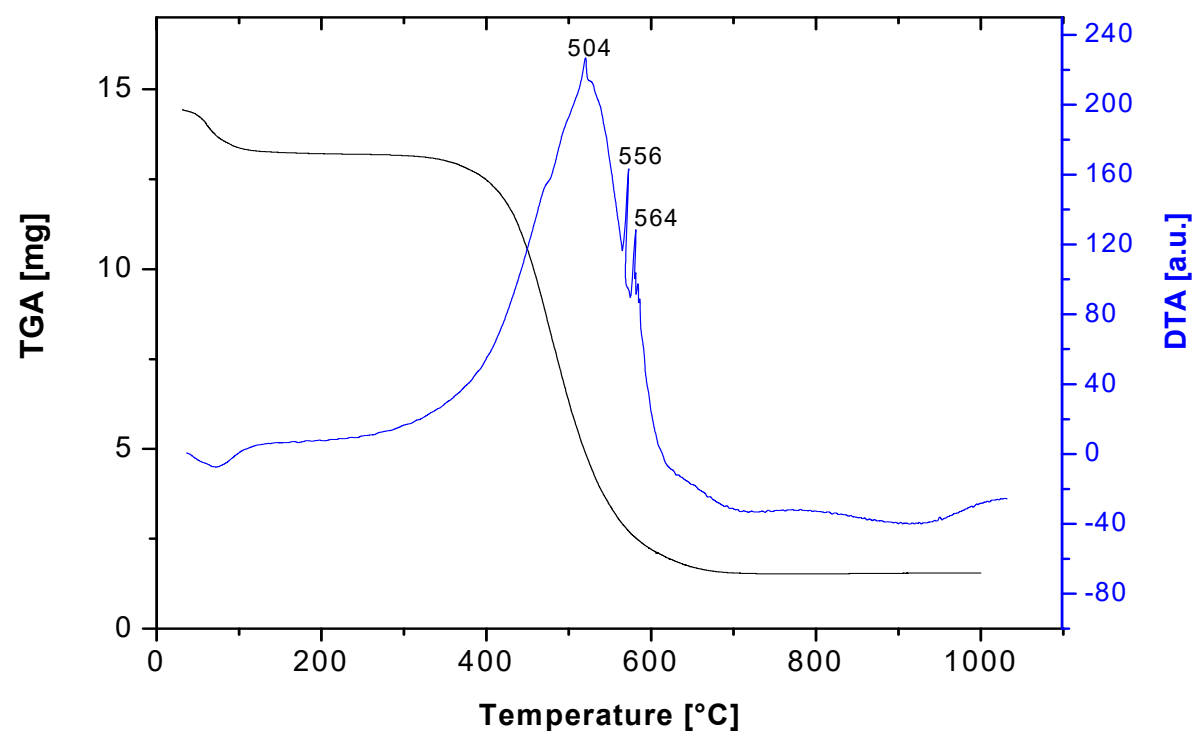

Figure 6: DTA-TGA of BWC. 
Due to the characteristics of the process, from which this residual material originates, and to the macroscopic observations, it is probable that the waste still contains material which has not been burnt. A curve with very similar peaks in DTA-TGA has been reported for the changes with temperature of mixtures with high proportions of calcium phosphates into hydroxyapatite structure [26].

The DTA-TGA profile corresponding to the brewery waste char is shown in Fig. 6. The analysis of the TGA curve determined that, at $25^{\circ} \mathrm{C}$, the initial weight of the sample is 14.43 $\mathrm{mg}$. As the temperature increases, the TGA curve starts to decrease. The first weight decrease is observed until $97^{\circ} \mathrm{C}$, with weight dropping to $13.27 \mathrm{mg}$. This represents a weight loss of $8 \%$ from the initial weight and can be assigned to loss of water and adsorbed gases. Between $330^{\circ} \mathrm{C}$ and $660^{\circ} \mathrm{C}$, the most important weight loss is produced, equivalent to $11.8 \mathrm{mg}$, which represents $81.8 \%$ of the sample's initial weight. This behaviour can be correlated to the obtained DTA curve, which also appears in the figure. Exothermic reactions are observed in a wide range of temperatures, with several peaks between $500^{\circ} \mathrm{C}$ and $570^{\circ} \mathrm{C}$.

Since lignin, cellulose and hemicellulose are intimately related in the whole structure, the thermal decomposition of each one cannot be analysed individually. However, it should be expected that lignin decomposition will occur at the highest temperature, while the hemicellulose degradation takes place at the lowest temperature. Taking these into account, it could be considered that the first two peaks are associated with cellulose and hemicellulose decomposition and the last one with lignin degradation. Pine sawdust char presents similar thermal behaviour to that of brewery waste char.

It is important to note that the reactions suffered by the residues during heating occur gradually as the temperature increases. Therefore, they can be used as aggregates in clay mixtures using the thermal programs habitually used in the ceramic industry, without structural problems in the brick.

To analyse the feasibility of reutilizing these residues in ceramic materials, the majority of oxides of commercial clay and those of the residue were taken to define the ternary diagram, from which to obtain a probable sintering temperature. For the $\mathrm{SHA}$ case, the $\mathrm{SiO}_{2}$ $\mathrm{Al}_{2} \mathrm{O}_{3}-\mathrm{MgO}$ diagram was taken, as shown in Fig. 7(a).
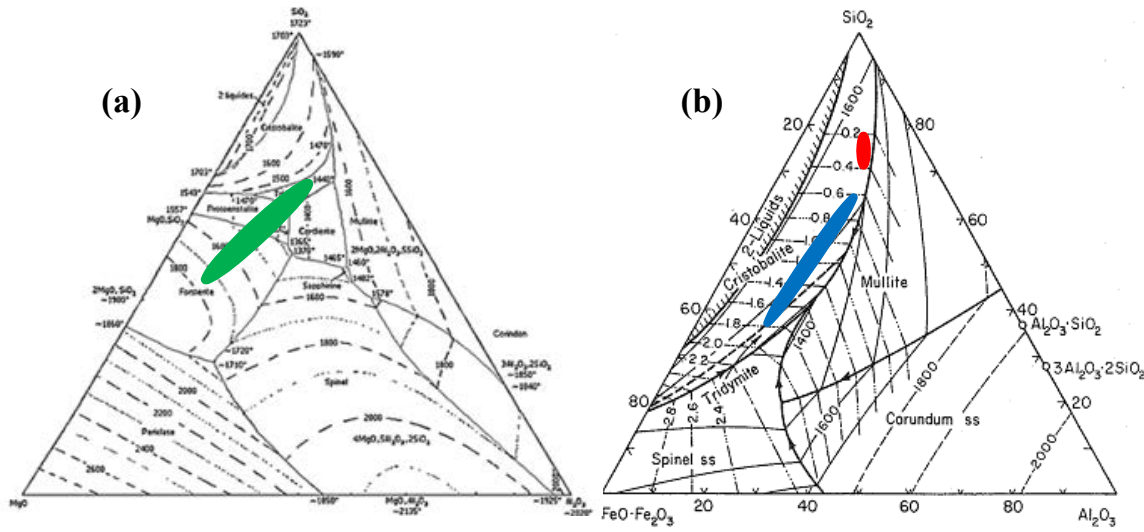

Figure 7: Ternary diagrams used to determine the theoretical sintering temperatures for mixtures of clay with: (a) SHA; (b) BWC and SC. 
Once the mixtures are located in the diagram (marked in green), it can be seen that the compositions with up to $30 \%$ of SHA are, in the compatibility diagram, defined by silica-cordierite-protoenstalite, where the temperature of the first liquid formation is approximately $1355^{\circ} \mathrm{C}$. Therefore, the probable sintering temperature would be $1015^{\circ} \mathrm{C}$, approximately. On the other hand, the mixtures with $40 \%$ and $50 \%$ of SHA added are in the cordierite-protoenstalite-forsterite compatibility triangle, whose temperature of first liquid formation would be $1365^{\circ} \mathrm{C}$, and the probable sintering temperature is $1025^{\circ} \mathrm{C}$.

For the case of brewery waste char and pine sawdust char, the $\mathrm{SiO}_{2}-\mathrm{Al}_{2} \mathrm{O}_{3}-\mathrm{FeO} \cdot \mathrm{Fe}_{2} \mathrm{O}_{3}$ diagram was taken to determine the sintering temperature of mixtures with up to $50 \%$ of residue added. In both cases, the temperature of first liquid formation is $1400^{\circ} \mathrm{C}$, and the probable sintering temperature would be $1050^{\circ} \mathrm{C}$. Fig. 7 (b) presents the ternary diagram used. The zone marked in blue corresponds to SC and the red to BWC.

The theoretical sintering temperatures calculated for clay-residue mixtures with up to $50 \%$ of added residue are in the range of those utilized in the ceramic industry $\left(950^{\circ} \mathrm{C}-1050^{\circ} \mathrm{C}\right)$.

\section{CONCLUSION}

The feasibility of reusing char and ashes from sunflower husks, brewery waste and pine sawdust as aggregates in clay mixtures for the production of ceramic materials for civil construction was analysed using different techniques.

The theoretical sintering temperatures calculated for clay-residue mixtures with up to $50 \%$ of residue are in the range of those utilized in the ceramic industry. The reactions that occur during the heating of the samples appear in a gradual way, so the incorporation of SHA, BWC or SC in a clayey matrix would not affect the structure of the brick.

Therefore, it is concluded that these wastes can be used as raw material for the production of ceramic products in the construction industry.

\section{ACKNOWLEDGEMENT}

The authors thank the National Agency for Scientific Promotion and the Scientific Research Commission of Buenos Aires Province for the financial support to develop this work.

\section{REFERENCES}

[1] Nunes, L.J.R., Matias, J.C.O. \& Catalão, J.P.S., Biomass combustion systems: A review on the physical and chemical properties of the ashes. Renewable and Sustainable Energy Reviews, 53, pp. 235-242, 2016.

[2] Niu, Y., Tan, H. \& Hui, S., Ash-related issues during biomass combustion: Alkaliinduced slagging, silicate melt-induced slagging (ash fusion), agglomeration, corrosion, ash utilization, and related countermeasures. Progress in Energy and Combustion Science, 52, pp. 1-61, 2016.

[3] Shi, R., Li, J., Jiang, J., Mehmood, K., Liu, Y., Xu, R. \& Qian, W., Characteristics of biomass ashes from different materials and their ameliorative effects on acid soils, Journal of Environmental Sciences, 55, pp. 294-302, 2017.

[4] Shi, R., Li, J., Xu, R. \& Qian, W., Ameliorating effects of individual and combined application of biomass ash, bone meal and alkaline slag on acid soils. Soil and Tillage Research, 162, pp. 41-45, 2016.

[5] Freire, M., Lope, H. \& Tarelho, L.A.C., Critical aspects of biomass ashes utilization in soils: Composition, leachability, PAH and PCDD/F. Waste Management, 46, pp. 304-315, 2015. 
[6] Wakizaka, H., Miyake, H. \& Kawahara, Y., Utilization of beer lees waste for the production of activated carbons: The influence of protein fractions on the activation reaction and surface properties. Sustainable Materials and Technologies, 8, pp. 1-4, 2016.

[7] Dodevski, V. et al., Plane tree seed biomass used for preparation of activated carbons (AC) derived from pyrolysis. Modeling the activation process. Colloids and Surfaces A: Physicochemical and Engineering Aspects, 522, pp. 83-96, 2017.

[8] Tan, X. et al., Biochar as potential sustainable precursors for activated carbon production: Multiple applications in environmental protection and energy storage. Bioresource Technology, 227, pp. 359-372, 2017.

[9] Wu, M., Li, R., He, X., Zhang, H., Sui, W. \& Tan, M., Microwave-assisted preparation of peanut shell-based activated carbons and their use in electrochemical capacitors. New Carbon Materials, 30(1), pp. 86-91, 2015.

[10] Martínez, M.L., Torres, M.M., Guzmán, C.A. \& Maestri, D.M., Preparation and characteristics of activated carbon from olive stones and walnut shells. Industrial Crops and Products, 23(1), pp. 23-28, 2006.

[11] Sklivaniti, V. et al., Valorisation of woody biomass bottom ash in Portland cement: A characterization and hydration study. Journal of Environmental Chemical Engineering, 5(1), pp. 205-213, 2017.

[12] González-Kunz, R.N., Pineda, P., Bras, A. \& Morillas, L., Plant biomass ashes in cement-based building materials. Feasibility as eco-efficient structural mortars and grouts. Sustainable Cities and Society, 31, pp. 151-172, 2017.

[13] Frías, M., Rodríguez, O., Sanchez de Rojas, M.I., Villar-Cociña, E., Rodrigues, M.S. \& Savastano Junior, H., Advances on the development of ternary cements elaborated with biomass ashes coming from different activation process. Construction and Building Materials, 136, pp. 73-80, 2017.

[14] Rosales, J., Cabrera, M., Beltrán, M., López, M. \& Agrela, F., Effects of treatments on biomass bottom ash applied to the manufacture of cement mortars. Journal of Cleaner Production, 154, pp. 424-435, 2017.

[15] Skripkiūnas, G., Macijauskas, M., Nagrockienè, D. \& Daugèla, A., The influence of biomass fly ash on the plasticizing effects in cement pastes. Procedia Engineering, 172, pp. 1015-1022, 2017.

[16] Kazmia, S.M.S., Abbas, S., Saleem, M.A., Munir, M.J. \& Khitab, A., Manufacturing of sustainable clay bricks: Utilization of waste sugarcane bagasse and rice husk ashes. Construction and Building Materials, 120(1), pp. 29-41, 2016.

[17] Kizinievic, O. \& Kizinievic, V., Utilisation of wood ash from biomass for the production of ceramic products. Construction and Building Materials, 127, pp. 264 273, 2016.

[18] Eliche-Quesada, D. \& Leite-Costa, J., Use of bottom ash from olive pomace combustion in the production of eco-friendly fired clay bricks. Waste Management, 48, pp. 323-333, 2016.

[19] Ooi, T.C. et al., The study of sunflower seed husks as a fuel in the iron ore sintering process. Minerals Engineering, 21(2), pp. 167-177, 2008.

[20] Oguntimein, G.B., Biosorption of dye from textile wastewater effluent onto alkali treated dried sunflower seed hull and design of a batch adsorber. Journal of Environmental Chemical Engineering, 3(4), pp. 2647-2661, 2015. 
[21] Casoni, A.I., Bidegain, M., Cubitto, M.A., Curvetto, N. \& Volpe, M.A., Pyrolysis of sunflower seed hulls for obtaining bio-oils. Bioresource Technology, 177, pp. 406409, 2015.

[22] Nigam, P.S., An overview: Recycling of solid barley waste generated as a by-product in distillery and brewery. Waste Management, 62, pp. 255-261, 2017.

[23] Qambrani, N.A., Rahman, M.M., Won, S., Shim, S. \& Ra, C., Biochar properties and eco-friendly applications for climate change mitigation, waste management, and wastewater treatment: A review. Renewable and Sustainable Energy Reviews, 79, pp. 255-273, 2017.

[24] Raclayská, H., Juhelková, D., Roubicek, V. \& Matýsek, D., Energy utilisation of biowaste - Sunflower seed hulls for co-firing with coal. Fuel Processing Technology, 92, pp. 13-20, 2011.

[25] Felipe-Sesé, M., Eliche-Quesada, D. \& Corpas-Iglesias, F.A., The use of solid residues derived from different industrial activities to obtain calcium silicates for use as insulating construction materials. Ceramics International, 37, pp. 3019-3028, 2011.

[26] Granados, F., Bonifacio, J. \& Serrano, J., Synthesis and characterization of calcium phosphate and its relation to $\mathrm{Cr}(\mathrm{VI})$ adsorption properties. Revista Internacional de Contaminación Ambiental, 26(2), pp. 129-134, 2010. 